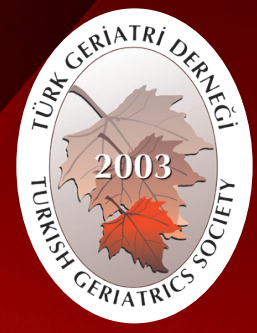

Turkish Journal of Geriatrics

DOI: 10.31086/tigeri.2019150566

2019;22 (1):2-8

- Ramazan ÖCAL ${ }^{1}$ (D)

- Yakup ARSLAN² D

CORRESPONDANCE

Ramazan ÖCAL

Health Sciences University, Gülhane

Medical Faculty, Department of Hematology,

Ankara, Turkey

Phone: 03123044107

e-mail: drocal@gmail.com

Received: 11/09/2018

Accepted: 15/12/2018

Health Sciences University, Gülhane

Medical Faculty, Department of Hematology

Ankara, Turkey

2 Health Sciences University, Gülhane Medical

Faculty, Department of Chest Diseases,

Ankara, Turkey

\title{
PROGNOSTIC VALUE OF HEMATOLOGICAL PARAMETERS IN GERIATRIC PATIENTS HOSPITALIZED IN INTENSIVE CARE UNITS
}

\section{Abstract}

Introduction: The aged bone marrow has a reduced proliferation ability in response to acute clinical status such as intensive care hospitalization. The presence of malnutrition, multiple chronic diseases, and comorbid conditions and the use of multiple pharmacological agents have an impact on the results of hematological tests. In this study, we aimed to determine the possible associations between complete blood counts and the prognosis and mortality of patients admitted to intensive care units.

Materials and Method: We retrospectively examined data of patients admitted to the intensive care unit between January 2014 and January 2016. We extracted complete blood count results and compared them based on age and mortality groups.

Results: We analyzed the data of 810 patients ( 548 geriatric and 262 non-geriatric patients). The overall mortality rate was $31.97 \%$; this was higher in geriatric than in non-geriatric patients $(p=0.01)$. We found the mean white blood cell counts in non-geriatric patients and the mean hemoglobin and hematocrit values and platelet counts in geriatric patients to be significantly lower than those in their counterparts $(p=0.05, p=0.01, p=0.02$, and $p=0.05$, respectively). While the mean hemoglobin and hematocrit values significantly lower in mortality group in both age populations, the mean platelet decrease was observed as a significant factor only in geriatric patients in terms of mortality $(p=0.01, p=0.04$ and $p=0.01$ respectively).

Conclusion: Close monitoring of hematological parameters, especially platelet counts in geriatric patients, and providing the necessary treatment will aid in a positive prognosis for patients in intensive care units.

Keywords: Hematological tests; Blood Cell Count; Geriatrics; Intensive care unit; Prognosis

ARAŞTIRMA

\section{HEMATOLOJIK PARAMETRELERIN YOĞUN BAKIM ÜNITESINDE YATAN GERIATRI YAŞ GRUBUNDAKI HASTALARDAKI PROGNOSTIK DEĞERi}

\section{$\ddot{O}_{z}$}

Giriş: Yaşlı kemik iliği, yoğun bakım hastanesi yatışı gibi akut klinik durumlara yanıt olarak azalmış bir proliferasyon kabiliyetine sahiptir. Malnütrisyon, çoklu kronik hastalıklar, komorbid durumlar ve çoklu farmakolojik ajanların kullanımı hematolojik testlerin sonuçları üzerinde etkilidir. Bu çalışmada, yoğun bakım ünitelerinde yatan hastaların tam kan sayımı ile prognoz ve mortalitesi arasındaki olası ilişkilerin belirlenmesi amaçlanmıştır.

Gereç ve Yöntem: Ocak 2014-Ocak 2016 tarihleri arasında yoğun bakım ünitesine başvuran hastaların verileri retrospektif olarak incelendi. Tam kan sayımı sonuçları yaş ve mortalite gruplarına göre karşılaştırıldı.

Bulgular: 810 hastanın (548 geriatri yaş grubunda olan ve 262 geriatri yaş grubunda olmayan hasta) verilerini analiz ettik. Genel mortalite oranı \%31.97 olup geriatrik olgularda geriatrik olmayanlara göre daha yüksekti $(p=0.01)$. Geriatri yaş grubunda olmayan hastalarda ortalama beyaz kan hücresi sayımı, geriatri yaş grubunda olan hastalarda ise ortalama hemoglobin, hematokrit değerleri ve trombosit sayıları anlamlı olarak düşüktü ( $p=0,05, p=0,01$, $p=0,02$ sırasıyla). Ortalama hemoglobin ve hematokrit değerleri, hem geriatri yaş grubunda olan ve olmayan hastalarda mortalite grubunda anlamlı derece düşükken ortalama trombosit sayısı sadece geriatri yaş grubunda olan hastalarda mortalite açısından belirleyici bulundu ( $p=0.01, p=0.04$ ve $p=0.01$ sirasiyla).

Sonuç: Hematolojik parametrelerin, özellikle trombosit sayısının yakından izlenmesi ve gerekli tedavinin sağlanması yoğun bakım ünitelerinde yatan geriatri yaş grubunda olan hastalarda iyi prognoz sağlanmasına yardımcı olacaktır.

Anahtar sözcükler: Hematolojik test; Tam kan sayımı; Geriatri, Yoğun bakım ünitesi; Prognoz 


\section{INTRODUCTION}

Developing health care services and increasing average life expectancies translate into increases in the geriatric population $(1,2)$. Turkey's population if current trends continued in demographic indicators will continue to aging. In the year 2012, the population aged 65 years and over is 5.7 million people, $7,5 \%$ of the total population. In the last five years, it increased by $17,1 \%$ and became 6 million 651 thousand 503 elderly people in 2016. The proportion of the elderly population in the total population rose to $8.3 \%$ in 2016 . By the year 2023, this population will increase to 8,6 million people and the rate will increase to $10,2 \%$ $(3,4)$. This number is close to the total population of most European countries, and it is inevitable that individuals $>65$ years of age be designated as a separate patient group in terms of community health $(1,2)$.

As well as hematological diseases, frequency of multiple chronic diseases also increases with aging. Hereby, geriatric patients represent many hospital admissions, particularly in the intensive care units (ICUs). In the geriatric patient group, wherein different comorbidities are frequent, changes in hematological parameters are also prominent and complete blood counts (CBCs) may vary widely, reflecting age-related comorbidities and treatment responses $(1,5,6)$. The aged bone marrow appears to have a reduced proliferation ability in response to acute clinical status such as severe illness, pernicious infections, acute blood loss, intensive care hospitalization. In addition, problems such as malnutrition, multiple chronic diseases, pharmacological agent uses, and presence of malignancies can cause changes in hematological parameters in this patient group $(5,6)$.

Considering aging as a known risk factor for mortality and the increasing number of geriatric
ICU admissions, we focused on evaluating hematological parameters in geriatric ICU patients. We aimed to reveal CBC result variability in ICU admissions according to age groups and to identify possible prognostic roles of the results in patients admitted to ICUs.

\section{MATERIALS AND METHOD}

We retrospectively examined data from patients hospitalized in the ICU of Internal Medicine Clinic between January 2014 and January 2016. The University Ethics Committee approved the study. We compiled demographic data, CBC results [white blood cell (WBC) and platelet counts and hemoglobin and hematocrit values] obtained upon ICU admission, ICU stay durations, additional clinical conditions, intubation status and mortalities during the patients' ICU stay. We classified data from patients aged $\geq 65$ years into the geriatric patient group, and those of patients aged $<65$ years into the non-geriatric patient group.

While the patients who were discharged from ICU were defined as "survival group", patients who died in ICU were defined as "death group". Statistical analyzes were performed among the identified groups. SPSS software (SPSS Inc, Chicago, IL) was used for statistical evaluation. In descriptive statistics, frequencies and percentages for discrete data, and means \pm standard deviations for continuous variables were used. The normality of the continuous variables was analyzed with the Kolmogorov-Smirnov test. Mean values with parametric distribution between groups were analyzed by Student's T test and ANOVA. Mean values with non-parametric distributions were compared by Mann-Whitney $U$ and Kruskal-Wallis tests. Probability $(p)$ values less than 0.05 were considered statistically significant. 


\section{RESULTS}

A total of 810 patients in the two groups, 548 geriatric patients and 262 non-geriatric patients, were hospitalized in the aforementioned ICU. Of these, 350 were women and 460 were men. Their mean age was $65.17 \pm 17.32$. Further, $67.65 \%$ of all patients were part of geriatric patient group, and $32.3 \%$ were part of the non-geriatric patient group.

General comparison between geriatric and non-geriatric patient groups

The mean age was $75.21 \pm 10.11$ in geriatrics and $44.16 \pm 17.38$ in non-geriatrics. APACHE II score, intubation frequency and mean ICU stay time were significantly higher in geriatric patients $(p=0.01$, $p=0.001$ and $p=0.003$ respectively). The mean WBC counts in non-geriatric patient group and the mean hemoglobin, hematocrit and platelet counts in geriatric patient group were significantly lower than those in their counterparts $(p=0.05, p=0.01$, $p=0.02$, and $p=0.05$, respectively) (Table 1 ). The mean ICU stay duration was $15.67 \pm 8.95$ days in non-geriatric patients group and $23.43 \pm 14.42$ days in geriatric patient group with a statistically significant difference $(p=0.03)$. The overall mortality rate was $31.97 \%$ (35.40\% in the geriatric patient group, $24.81 \%$ in the non-geriatric patient group) and the difference between patient groups was statistically significant $(p=0.01)$. The clinical and laboratory findings of the two groups are summarized in Table 1.

Comparison between geriatric and nongeriatric patient groups requiring intubation

Of the 630 patients who required intubation by invasive mechanical ventilation, 462 were geriatric patients (84.30\%) and 168 were nongeriatric patients (64.12\%). Intubation frequency was significantly higher in geriatric patients $(p=0.02)$. APACHE II score, mean ICU stay time and mean ventilator days were significantly higher in geriatric patients $(p=0.03, p=0.02$ and $p=0.01$ respectively). The mean hemoglobin and hematocrit values and platelet counts were significantly lower $(p=0.01, p=0.01, p=0.04$, respectively) in the intubated geriatric patient group than in the intubated non-geriatric patient group. The mortality rate in the intubated geriatric patient group was significantly higher (40.04\%) than in the intubated non-geriatric patient group ( $p=0.01)$ (Table 2).

Comparison between survival and mortality groups

Of the 810 patients followed in ICU for 2 years, 551 were discharged from ICU, and 259 died during their stay. The overall mortality rate was $31.97 \%$; it was higher in geriatric patients. When CBC data were analyzed, low mean hemoglobin and hematocrit values and platelet counts were more frequent in patients who died than in those who were discharged $(p=0.02, p=0.01$, and $p=0.05$, respectively) (Table 3 ). When mortality groups were evaluated as subgroups according to age, there were different as well as common mortality risk factors between geriatric and non-geriatric cases. While the mean hemoglobin and hematocrit values significantly lower in mortality group in both age populations, the mean platelet decrease was observed as a significant factor only in geriatric patients in terms of mortality $(p=0.01, p=0.04$ and $\mathrm{p}=0.01$ respectively). 
Table 1. Comparison of clinical findings of patients according to age groups.

\begin{tabular}{|c|c|c|c|c|}
\hline \multirow{2}{*}{\multicolumn{2}{|c|}{ Characteristics }} & $\begin{array}{r}\text { Non-geriatric patient group } \\
\mathrm{n}(\%)\end{array}$ & $\begin{array}{r}\text { Geriatric patient group } \\
\mathrm{n}(\%)\end{array}$ & $\mathrm{p}$ \\
\hline & & $262(32.35 \%)$ & $548(67.65 \%)$ & 0.01 \\
\hline \multirow{2}{*}{$\operatorname{Sex}(n, \%)$} & Female & $117(44.66 \%)$ & $233(42.52 \%)$ & NS \\
\hline & Male & $145(55.34 \%)$ & $315(57.48 \%)$ & NS \\
\hline \multicolumn{2}{|c|}{ Mean age (year) } & $44.16 \pm 17.38$ & $75.21 \pm 10.11$ & - \\
\hline \multicolumn{2}{|l|}{ APACHE II } & $15.34 \pm 5.45$ & $22.56 \pm 6.32$ & 0.01 \\
\hline \multicolumn{2}{|c|}{ Intubation (n, \%) } & $168(64.12 \%)$ & $462(84.31 \%)$ & 0.001 \\
\hline \multicolumn{2}{|c|}{ Mean ICU stay (days) } & $11.67 \pm 8.95$ & $23.43 \pm 14.42$ & 0.03 \\
\hline \multicolumn{2}{|l|}{ Mortality } & $24.81 \%$ & $35.40 \%$ & 0.01 \\
\hline \multicolumn{2}{|c|}{ Mean WBC ( $\times 10^{3}$ cell $\left./ \mu L\right)$} & $8.650 \pm 2.560$ & $12.350 \pm 4.130$ & 0.05 \\
\hline \multicolumn{2}{|c|}{ Mean hemoglobin ( $\mathrm{g} / \mathrm{L}$ ) } & $11.3 \pm 4,1$ & $9.7 \pm 3.2$ & 0.01 \\
\hline \multicolumn{2}{|c|}{ Mean hematocrit (\%) } & $34.2 \pm 6.7$ & $28.6 \pm 7.6$ & 0.02 \\
\hline \multicolumn{2}{|c|}{ Mean platelet $\left(\times 10^{3} \mathrm{cell} / \mu \mathrm{L}\right)$} & $213.000 \pm 95.000$ & $186.000 \pm 113.000$ & 0.05 \\
\hline
\end{tabular}

NS, not significant; WBC, white blood cell; ICU, intensive care unit

Table 2. Comparison of clinical findings between intubated non-geriatric patient and intubated geriatric patient groups.

\begin{tabular}{|c|c|c|c|c|}
\hline \multicolumn{2}{|c|}{ Characteristics } & $\begin{array}{r}\text { Intubated non-geriatric } \\
\text { patients }\end{array}$ & $\begin{array}{r}\text { Intubated geriatric } \\
\text { patients }\end{array}$ & p \\
\hline \multicolumn{2}{|l|}{$n, \%$} & $168(64.12 \%)$ & $462(84.31 \%)$ & 0.02 \\
\hline \multirow{2}{*}{$\operatorname{Sex}(n, \%)$} & Female & 92 (54.76\%) & 194 (41.99\%) & NS \\
\hline & Male & $76(45.24 \%)$ & $268(58.01 \%)$ & NS \\
\hline \multicolumn{2}{|c|}{ Mean age (year) } & $55.11 \pm 14.58$ & $76.01 \pm 10.15$ & - \\
\hline \multicolumn{2}{|l|}{ APACHE II } & $19.33 \pm 6.15$ & $24.28 \pm 6.85$ & 0.03 \\
\hline \multicolumn{2}{|c|}{ Mean ICU stay (days) } & $15.74 \pm 6.81$ & $24.36 \pm 13.456$ & 0.02 \\
\hline \multicolumn{2}{|c|}{ Mean ventilator days } & $7.78 \pm 2.34$ & $17.62 \pm 8.9$ & 0.01 \\
\hline \multicolumn{2}{|c|}{ Mean ventilator-free days } & $7.96 \pm 2.12$ & $6.74 \pm 1.9$ & NS \\
\hline \multicolumn{2}{|l|}{ Mortality } & $22.62 \%$ & $40.04 \%$ & 0.001 \\
\hline \multicolumn{2}{|c|}{ Mean WBC ( $\times 10^{3}$ cell $\left./ \mu \mathrm{L}\right)$} & $9.150 \pm 2.320$ & $12.150 \pm 5.450$ & 0.05 \\
\hline \multicolumn{2}{|c|}{ Mean hemoglobin (g/L) } & $11.7 \pm 3.9$ & $8.6 \pm 2.1$ & 0.01 \\
\hline \multicolumn{2}{|c|}{ Mean hematocrit (\%) } & $33.1 \pm 6.3$ & $26.3 \pm 5.7$ & 0.01 \\
\hline \multicolumn{2}{|c|}{ Mean platelet $\left(\times 10^{3}\right.$ cell $\left./ \mu \mathrm{L}\right)$} & $205.000 \pm 110.000$ & $177.000 \pm 98.000$ & 0.04 \\
\hline
\end{tabular}

NS, not significant; WBC, white blood cell; ICU, intensive care unit 
Table 3. Comparison of general clinical findings of survival and mortality groups.

\begin{tabular}{|c|c|c|c|}
\hline Characteristics & Survival group & Mortality group & $\mathrm{p}$ \\
\hline n (\%) & $551(68.02 \%)$ & $259(31.97 \%)$ & - \\
\hline Age (years) & $60.39 \pm 12.76$ & $75.45 \pm 11.32$ & 0.05 \\
\hline Mean WBC $\left(\times 10^{3}\right.$ cell/ $\left./ \mu \mathrm{L}\right)$ & $8.330 \pm 3.230$ & $14.547 \pm 6.780$ & NS \\
\hline Mean hemoglobin (g/L) & $12.1 \pm 3.5$ & $8.6 \pm 2.8$ & 0.02 \\
\hline Mean hematocrit (\%) & $34.3 \pm 7.4$ & $25.7 \pm 4.6$ & 0.01 \\
\hline Mean platelet $\left(\times 10^{3}\right.$ cell $\left./ \mu \mathrm{L}\right)$ & $220.000 \pm 85.300$ & $164.370 \pm 94.200$ & 0.05 \\
\hline IMV & $36(5.71 \%)$ & $223(35.39 \%)$ & 0.001 \\
\hline Mean ICU stay (days) & $11.31 \pm 8.92$ & $23.12 \pm 11.35$ & 0.01 \\
\hline
\end{tabular}

NS: not significant; WBC: white blood cell, IMV: invasive mechanical ventilation

\section{DISCUSSION}

The rapid increase in geriatric population results in the emergence of this patient group in intensive care units. Therefore, intensive care data of geriatric patients are privileged in predicting their prognosis and mortality. From this point of view, in this study we evaluated the effects of hematological parameters on prognosis by examining the intensive care data of geriatric patients. 548 geriatric and 262 non-geriatric patients were included in the study and the mortality rate was significantly higher in geriatric patients $(p=0.01)$. There was also a significant difference between the groups in terms of hematological parameters. The mean white blood cell (WBC) counts in non-geriatric patients and the mean hemoglobin and hematocrit values and platelet counts in geriatric patients to be significantly lower than those in their counterparts $(p=0.05, p=0.01, p=0.02$, and $p=0.05$, respectively). While low hemoglobin and hematocrit values were significant in mortality group in both age populations, a low mean platelet count was a significant determinant of mortality in only geriatric patients ( $p=0.01, p=0.04$ and $p=0.01$ respectively).

It is well known that hemopoietic system undergoes significant age-associated functional changes. However, the functional mechanisms of this situation are still controversial. Data from animal models have suggested that an expansion of defective stem and progenitor cells may occur in the aging bone marrow. In an ancient study which is one of pioneers in animal studies, replicative capacity of hemopoietic stem cells was found to progressively decline upon serial transplantation in in mouse models and it was interpreted as these cells may become exhausted with age (7). It has been demonstrated by several invastigations that by age of 70 years, the hematopoietic cellularity of bone marrow is reduced to about $30 \%$ of that of young adults (8). On the other hand, the current opinion about the aging hemopoietic system is that age-related modifications of bone marrow are not reflected in the hemogram in healthy elderly people. These changes, however, may become clinically evident under conditions of severe hemopoietic stress such as severe illness, intensive care hospitalization. (9-11).

Some ICU stay data of geriatric patients and data regarding age-related mortality rates and hemogram parameters are available in the current literature (1215). In our ICU, we have our own research results in this area. In our study of 135 acute respiratory distress syndrome cases, we found mortality rates to be higher in geriatric patients. In another retrospective study of our ICU, advanced age was identified as a risk factor for ventilator-associated pneumonia (16). 
Studies on the effects of hematological and biochemical parameters on prognosis and mortality are also available $(17,18)$. Low albumin and high creatinine levels have been identified as mortality risk factors in geriatric patients (18). In a study conducted by Ponzetto et al. in geriatric patients, serum albumin, fibrinogen, and creatinine levels were identified as independent risk factors for mortality (19). Similar to our results, in another study, low serum albumin and hemoglobin levels were associated with mortality in geriatric patients (12). In the study of Fontana et al., erythrocyte sedimentation rate, C-reactive protein level, insulin-like growth factor level, triiodothyronine level, serum albumin level, iron level, total cholesterol level, and low-density lipoprotein cholesterol level together with WBC and lymphocyte counts were associated with mortality in geriatric patients in accordance with our findings in terms of WBC (20). Studies have also shown that the red blood cell distribution width and serum vitamin B12 levels may predict mortality in geriatric inpatient populations (21-23).

In the study of Frąckiewicz et al. several hematological parameters were found to be inversely associated with a risk of all-cause mortality among men, but not among women in older people (24). Whereas, they found no similar associations for red blood cell, hemoglobin and hematocrit levels. This finding was interpreted as a result of a difference

\section{REFERENCES:}

1. Sacanella E, Perez-Castejon JM, Nicolas JM, et al. Mortality in healthy elderly patients after ICU admission. Intensive Care Med 2009;35:550-5. (PMID:18982308)

2. Fuchs L, Chronaki CE, Park S, et al. ICU admission characteristics and mortality rates among elderly and very elderly patients. Intensive Care Med 2012;38:1654-61. (PMID:22797350).

3. Population Projections, 2013-2075. Turkey Statistical Institute Newsletter. 2013;15844. [Internet] Available from: http://www.tuik.gov.tr/PreHaberBultenleri. do?id=15844. Accessed: 01.09.2018. (in Turkish). in iron metabolism between genders. However, our results did not differ significantly between the genders.

Despite all our literature searches, we could not find sufficient data on the association between hematological test results and the prognosis of geriatric patients in intensive care units. In this respect, we think that the results obtained in our study will help clinicians.

As a conclusion, the aged bone marrow has a reduced proliferation ability in response to severe clinical status such as intensive care hospitalization. It makes the result inevitable that hematological parameters of patients in ICU show significant differences between geriatric and nongeriatric patient groups. Careful monitoring of the hematological data in geriatric patients and appropriate blood product transfusion such as platelet replacement treatments when needed will improve their prognosis.

\section{ACKNOWLEDGEMENTS}

We thank to Prof. Dr. H. Levent Yamanel due to the contributions about using the archive of ICU.

\section{Conflicts of interest}

The authors of this article state that they have no conflict of interest.

4. Elderly with Statistics, 2016. Turkey Statistical Institute Newsletter. 2017;24644. [Internet] Available from: http://www.tuik.gov.tr/PreHaberBultenleri. do?id=24644. Accessed: 01.09.2018. (in Turkish).

5. Migone De Amicis M, Poggiali E, Motta I, et al. Anemia in elderly hospitalized patients: prevalence and clinical impact. Intern Emerg Med 2015 Aug 10 (5):581-6. (PMID:25633233).

6. Meinders AJ, van der Hoeven JG, Meinders AE. The outcome of prolonged mechanical ventilation in elderly patients: are the efforts worthwhile? Age Ageing 1996;25:353-6. (PMID:8921138). 
7. Albright JW, Makinodan T. Decline in the growth potential of spleen-colonizing bone marrow stem cells of long-lived aging mice. J Exp Med 1976;144:120421. (PMID:993725).

8. Gilleece $\mathrm{MH}$, Dexter TM. The biological ageing of bone marrow. Rev Clin Gerontol 1993;3:317-25.

9. Inelmen EM, D'Alessio M, Gatto MR et al. Descriptive analysis of the prevalence of anemia in a randomly selected sample of elderly people living at home: some results of an Italian multicentric study. Aging (Milano). 1994;6:81-9 (PMID:7918735).

10. Rothstein G. Hematopoiesis in the aged: a model of hematopoietic dysregulation? Blood 1993;82:2601-04 (PMID:8219213).

11. Pinto A, Filippi RD, Frigeri $F$, et al. Aging and the hemopoietic system. Critical Reviews in Oncology/ Hematology 48S (2003) S3-S12.

12. Ocal N, Dogan D, Taskin G, Yildiz B, Ozer S, Yamanel $\mathrm{HL}$. Continual assessment of mortality risk factors in geriatric patients hospitalized in intensive care due to pneumonia. Turkish Journal of Geriatrics 2016;19(1):1-8.

13. Gok DE, Dogru T, Turhan $V$, et al. Diagnosis and the treatment of the chronic disease anemia in the elderly. Turkish Journal of Geriatrics 2000;3(4):163-8.

14. Icme F, Dogan NO, Yuzbasioglu Y, et al. Prognostic relationship between complete blood count parameters and transient ischemic attack, ischemic stroke and hemorrhagic stroke. Turkish Journal of Geriatrics 2014;17(1):23-8.

15. Ezerarslan $\mathrm{H}$, Başaran M. Hematologıc parameters in geriatrıc patients with idiopathic sudden sensorineural hearing loss. Turkish Journal of Geriatrics 2016;19(1):35-41.

16. Ocal N, Ocal R, Ozer S, Taskin G, Dogan D, Yamanel $\mathrm{HL}$. Prognostic value of unchangeable risk factors for and the radiologic scoring system in ventilatorassociated pneumonia. Yoğun Bakım Derg 2016;7:448. (in Turkish).
17. BachV, Schruckmayer G, Sam I, Kemmler G, Stauder R. Prevalence and possible causes of anemia in the elderly: a cross-sectional analysis of a large European university hospital cohort. Clin Interv Aging 2014; 9: 1187-96. (PMID:25092968)

18. Boumendil A, Somme D, Garrouste-Orgeas M, Guidet B. Should elderly patients be admitted to the intensive care unit? Intensive Care Med 2007;33:125262. (PMID:17404703).

19. Ponzetto $M$, Maero $B$, Maina $P$, et al. Risk factors for early and late mortality in hospitalized older patients: the continuing importance of functional status. J Gerontol A Biol Sci Med Sci 2003;58(11):1049-54. (PMID:14630889).

20. Fontana L, Addante F, Copetti M, et al. Identification of a metabolic signature for multidimensional impairment and mortality risk in hospitalized older patients. Aging Cell 2013;12(3):459-66. (PMID:23496093).

21. Demircan F, Gozel N, Kilinc F, Ulu R, Atmaca M. The Impact of Red Blood Cell Distribution Width and Neutrophil/Lymphocyte Ratio on the Diagnosis of Major Depressive Disorder. Neurol Ther. 2016 Jun;5(1):27-33. (PMID:26686339).

22. Smelt AF, Gussekloo J, Bermingham LW, et al. The effect of vitamin B12 and folic acid supplementation on routine haematological parameters in older people: an individual participant data meta-analysis. Eur J Clin Nutr. 2018 Jun;72(6):785-95. (PMID:29520083).

23. Martínez-Velilla N, Ibáñez B, Cambra K, AlonsoRenedo J. Red blood cell distribution width, multimorbidity, and the risk of death in hospitalized older patients. Age (Dordr) 2012;34(3):717-23. (PMID:21544577).

24. Frąckiewicz J, Wlodarek D, Brzozowska A, et al. Hematological parameters and all-cause mortality: a prospective study of older people. Aging Clin Exp Res 2018;30:517-26. (PMID:28664457). 